Canadian University Music Review

Canadian University Music Review

Revue de musique des universités canadiennes

John Rink. Chopin: The Piano Concertos. Cambridge Music

Handbooks. Cambridge: Cambridge University Press, 1997. x,

139 pp. ISBN 0-521-44109-9 (hardcover), 0-521-44660-0 (paperback)

\title{
Glen Carruthers
}

Volume 20, numéro 2, 2000

URI : https://id.erudit.org/iderudit/1014466ar

DOI : https://doi.org/10.7202/1014466ar

Aller au sommaire du numéro

\section{Éditeur(s)}

Canadian University Music Society / Société de musique des universités canadiennes

\section{ISSN}

0710-0353 (imprimé)

2291-2436 (numérique)

Découvrir la revue

Citer ce compte rendu

Carruthers, G. (2000). Compte rendu de [John Rink. Chopin: The Piano Concertos. Cambridge Music Handbooks. Cambridge: Cambridge University Press, 1997. x, 139 pp. ISBN 0-521-44109-9 (hardcover), 0-521-44660-0 (paperback)]. Canadian University Music Review / Revue de musique des universités canadiennes, 20(2), 119-125. https://doi.org/10.7202/1014466ar

All Rights Reserved ( C Canadian University Music Society / Société de musique des universités canadiennes, 2000
Ce document est protégé par la loi sur le droit d'auteur. L'utilisation des services d'Érudit (y compris la reproduction) est assujettie à sa politique d'utilisation que vous pouvez consulter en ligne.

https://apropos.erudit.org/fr/usagers/politique-dutilisation/ 
may have been hastened by the increasing number of female performers on the instrument. ${ }^{1}$ One who surely should have received mention is Lisa Cristiani (182753), to whom Mendelssohn dedicated his only solo work for that instrument.

This one criticism aside, I found Walden's overall approach refreshing in that she does not attempt to mask the fact that different practices co-existed and that no one approach is necessarily valid when attempting to play in a historically informed manner. Cellists may enjoy reading Pierre Marie Baillot's description of the problem of holding the ensemble together, or what the Italians called tempo disturbato, a type of rubato that soloists engaged in, during which the cello was expected to serve as the "regulator" of the ensemble and hold the tempo steady (p.248). Walden also highlights Romberg's account of tempo variations encountered by touring cellists, such as the allegro being faster "in Paris than in Vienna, and in Vienna, again, faster than in the north of Germany" ( $p$. 248). Another fascinating example demonstrates chordal realization of recitative, with the double bass playing sustained notes and the cello playing two-, three-, and four-note chords (p. 264). ${ }^{2}$ Both Johann Georg Christoph Schetky and Jean Baumgartner advised that chords on the cello were to be struck just after the singer had pronounced each syllable of text. The performances in Mannheim by Peter Ritter (1763-1846), who used scordatura in several concertos and employed bariolage figures (an alternation between stopped note and open string at unison) for unusual sonority with his cello tuned in B-flat (a halfstep higher than the orchestra), were a novel approach to combining different pitch levels.

These few illustrations only sample the wealth of new material and possibilities for different approaches demonstrated in the volume. There are literally dozens of musical examples, and the appendices provide a useful chronological list of thirty cello methods published between 1741 and 1855 as well as a good selected bibliography. Walden's book is a fascinating and in-depth account of an extraordinarily rich and varied period of performance practice. It makes engaging reading and is sure to remain a valuable resource for cellists and one that can profitably serve other string players as well.

Mary Cyr

John Rink. Chopin: The Piano Concertos. Cambridge Music Handbooks. Cambridge: Cambridge University Press, 1997. x, 139 pp. ISBN 0-521-44109-9 (hardcover), 0-521-44660-0 (paperback).

John Rink's consideration of Chopin's concertos, including the rarely-heard Allegro de concert, op. 46, embraces much more than the genesis, reception, form, and structure of three of the composer's most controversial works. Not that these important matters are overlooked; rather, in the course of his investigation, which includes a survey of other concertos of the period, a chapter on

\footnotetext{
${ }^{1}$ Tilden A. Russell, "The development of the cello endpin," Imago musicae 4 (1987): 335-356.

${ }^{2}$ The example is taken from Bernard Stiastny, Violoncell-Schule (Mainz: Georges-Zulehner,[1829]),p. 21.
} 
interpretation, and detailed analyses of each of the three works, Rink "attempts to set the record straight, re-evaluating the concertos against the early nineteenth-century traditions that shaped them so that their many outstanding qualities can be better appreciated" (p. ix). In his analyses, Rink employs "performance-related criteria ... [in an effort] to redress the anachronistic and tendentious criticisms of past authors" (p. ix), from Frederich Niecks, whose study of Chopin appeared in 1888, to Michael Roeder, whose History of the Concerto appeared in 1994. Rink's contention is that Niecks's criticisms of Chopin's concertos so influenced later writers, including Huneker, Leichentritt, Weissmann, Scharlitt, Abraham, Hedley, Weinstock, and Roeder, that a "coalescence of critical response [is manifest in] three recurrent, almost inevitable criticisms"; namely, that the formal plan, working out of themes, and orchestration of all three works are substandard (pp. 29-30).

Rink's approach in chapter 1 is to place Chopin's concertos in the context of the early nineteenth-century piano concerto and of the composer's other early works. He reviews the genesis, early critical reception, first editions, and Chopin's pedagogical use of the concertos in chapter 2. Chapter 3 discusses interpretation from the standpoint of critics, editors, and performers, while chapter 4 attempts a re-evaluation of the concertos by surveying the form and tonal plan, and then supplying an analytical narrative for each movement. The final chapter is given over to Chopin's "third piano concerto," the Allegro de concert, and appendices include bibliographies of reviews and editions, and a short discography. That all this even attempted, much less achieved, in only 130 pages is a testament to the author's focus and concision.

Rink places Chopin's concertos squarely in the virtuoso tradition, distinct from the more symphonic works of Beethoven, Liszt, and Brahms. The stile brillante is linked to the world of opera, evident in the important recitativo passages in Moscheles's Piano Concerto in G Minor and in Chopin's own Piano Concerto in F Minor (p. 3). Virtuoso concertos in Chopin's concert repertoire, which doubtless influenced his own contributions to the genre, include works by Gyrowetz, Ries, Hummel, Moscheles, and Kalkbrenner (p. 5). This, then, establishes the broad context in which Chopin's contributions emerge as among the finest concertos of the early romantic era.

The position of the concertos in Chopin's output is explored in detail. His early compositions extend from his apprenticeship in Warsaw, through his sojourns to Vienna in 1829 and 1830-31, to the works composed just after his arrival in Paris in August 1831. Rink divides these pieces into three groups: "private" chamber music (including the Piano Sonata, op. 4, and Trio in G Minor, op. 8), smaller genres for mostly private performances (including the songs), and concert music (to which the variations, rondos, and concertos belong).

Rink regards the Fantasy on Polish Airs, op. 13, and the Rondo à la krakowiak, op. 14, both composed in 1828 and belonging to the concert music category, as major advances over Chopin's earlier works. In particular, their introductions, and that to the "Là ci darem" Variations, op. 2, of 1827, are important harbingers of the more personal and mature style evident in opp. 11 and 21, both completed in 1830. The concertos are shown to be a curious hybrid of Chopin's 
private and public styles, since their tonal schemes have more in common with the private genres than with the other works in the concert music group.

Yet Rink's suggestion that there is a parallel between the structure of Chopin's mazurkas and his concertos is not entirely convincing. If it is true that "repeating ideas throughout the seemingly disparate parts of a work [ensures] an 'organic' unity for his mazurkas-and indeed the concertos" (pp.10-11), it is not at all clear why rondos and variations, which comprise much of the virtuosic repertoire of the 1820s and which, after all, are built on the principle of thematic repetition, do not and "could never" achieve an advanced degree of thematic integration (p.11). Similarly, Rink's view that the energetic finales to the concertos, in common with several other works in the concert music group, speak to a "heightened sensitivity to closure" (p. 10) seems less to the point than the simple fact that "flashy" codas are normative in works intended for public performance. Less a heightened sense of closure, I would think, than a surefire way to elicit applause.

It is also debatable whether the unorthodox tonal relationships in the first movements of opp. 11 and 21 represent a successful experiment, first broached in Chopin's miniatures from the same period, or, as other authors have suggested, evince "ignorance of the Viennese sonata principle" (p. 10). Rink raises this intriguing question, but is unable to resolve it satisfactorily in the space allotted to him. This is not so much a criticism as it is a caution. Rink poses many questions, but can do little more than hint at the answers. The book's brevity, too, precludes more than a handful of musical examples; more would have helped elucidate the questions raised, even if the answers were not immediately forthcoming. Fortunately, Rink has written "elsewhere" on some of the issues raised in this handbook, and the conscientious reader would do well to seek out his articles from the early 1990 s on interpretation and tonal architecture. ${ }^{1}$

The second chapter, "Creation," explores the concertos' geneses, premieres, and editions. Of considerable interest, in light of Rink's efforts to rehabilitate the concertos, is an overview of their early reception. That, in the $1830 \mathrm{~s}$, the Powszechny dziennik krajowy and Kurier warszawski refer to the success of the tuttis and orchestration respectively of the F Minor Concerto, and that the Powszechny dziennik krajowy makes mention of the "perfect orchestration" of the E Minor Concerto, gives credence to Rink's view that it was only later that the efficacy of Chopin's orchestration came into serious question. ${ }^{2}$ It is likely that the only negative reference to Chopin's orchestration in these early reviews had more to do with the composer's "weak sound" at the piano than with his "heavy orchestration" per se (p. 18).

\footnotetext{
1 John Rink, "Authentic Chopin: History, Analysis and Intuition in Performance," in Chopin Studies 2, ed. John Rink and Jim Samson (Cambridge: Cambridge University Press, 1994), 214-44; John Rink, "Tonal Architecture in the Early Music," in The Cambridge Companion to Chopin, ed. Jim Samson (Cambridge: Cambridge University Press, 1992), 78-97.

${ }^{2}$ As Rink notes (p. 28), Louis Ehlert and Wilhelm von Lenz anticipate Niecks and other later critics. See Louis Ehlert, Aus der Tonwelt, 2nd ed. (Berlin, 1882) and Wilhlem von Lenz, "Uebersichtliche Beurtheilung der Pianoforte-Kompositionen von Chopin," Neue Berliner Musikzeitung 26 (1872): 282-83.
} 
The discourses on "Chopin as teacher" at the end of chapter 2 and on "Interpretation" in chapter 3 are made meaningful only by frequent reference to the score. Readers are hereby advised that from this point onwards the book should be read with the music in hand. Rink's look at Chopin's teaching is necessarily confined to less than three pages, and Jean-Jacques Eigeldinger's superb monograph on the topic should be consulted for a much more complete view. ${ }^{3}$

It is Rink's opinion that "once divorced from the unique performance aesthetic that had guided their creation, the concertos no longer communicated the expressive message that Chopin himself had brought to life as composer, performer and teacher" (p.24). Rink attempts to recreate, by examining critical opinion, editions, and recorded performances, the "extraordinary diversity" of Chopin interpretation over the past century and a half. If, as Rink suggests, it is true that "the degree to which [a musical work] can endure a multiplicity of readings without suffering 'depletion' may be one measure of its aesthetic value," his conclusion that "Chopin's concertos are truly great works" seems plausible enough (p. 25). Certainly, the concertos have withstood a number of transcriptions and arrangements, including the now largely discredited reorchestrations of Tausig and Balakirev (op. 11) and Klindworth and Messager (op. 21), as well as an astonishing range of recorded performances. Rink surveys what he calls the "most important" recordings, including several performances that he considers deplorable. Fou Ts'ong's "sepia performance, despairing in tone" of op. 11 is quickly dismissed, as is Adam Harasiewicz's "forlorn," "deadpan," and "cack-handed" reading of the same work (p.41). How these recordings fall under the rubric of "most important" is never explained.

In the F Minor Concerto, Rink favours Ashkenazy, Askenase, Cortot, Hoffman, and Perahia. At the other end of the spectrum is the Argerich/ Rostropovich collaboration for Deutsche Grammophon: "It is ... astonishing that Argerich's op. 21 is so inept-in part the fault of Mstislav Rostropovich, whose orchestral tuttis are huge and intrusive, while the piano plays mere passagework, with a strident tone to boot" (p. 42). In the E Minor Concerto, Rink prefers Argerich, Czerny-Stefanska, Lipatti, and Pollini. Rink admits that, despite her failure in op. 21, Argerich's op. 11 "is probably best, given the symbiotic partnership between piano and orchestra" (p. 42).

It is instructive to compare Rink's critiques with those of James MethuenCampbell, whose comprehensive if not especially scholarly study of Chopin interpretation remains a benchmark for assessing reception history on the basis of recorded performances. ${ }^{4}$ It may be, as Rink suggests, that a "successful performance ... can occur only when its constituent parts 'add up' to a coherent conception, to a hierarchy of temporally defined musical gestures ranging from the smallest level of progression to the large-scale controlling shape" (p. 39).

\footnotetext{
${ }^{3}$ Jean-Jacques Eigeldinger, Chopin: Pianist and Teacher as Seen by His Pupils, trans. Naomi Shohet with Krysia Osostowicz and Roy Howat, ed. Roy Howat (Cambridge: Cambridge University Press, 1986).

${ }^{4}$ James Methuen-Campbell, Chopin Playing from the Composer to the Present Day (London: Victor Gollancz, 1981).
} 
Nonetheless, there is much room for disagreement on specific performances. Methuen-Campbell argues that Argerich's op. 11 is in some respects "more hectic than tranquil" and recalls that "her critics have described this performance as neurotic." Rink rejects the live recording of op. 11 by Rosina Lhévinne, noting that Bella Davidovich, "who pedantically counts the Rondo's finale and injects gratuitous touches ... seems polished" by comparison (p. 41). MethuenCampbell, on the other hand, writes glowingly for almost a page about Lhévinne's recording, concluding that "it is a pity that [she] did not make more recordings of the solo works of Chopin, for this performance is so interesting from an interpretative angle." ${ }^{\prime 6}$ Rink may have a sound basis for his views, but taste remains the final arbiter.

Besides critics, editors, arrangers, and performers, composers play a role in reception history by absorbing the stylistic influences of their predecessors and contemporaries. Rink elects not to address this issue beyond noting that Hans Engel identifies Arensky, Fauré, Jadassohn, Paderewski, Potter, Prout, Rubinstein, Skryiabin, and Wolff as composers whose works for piano and orchestra bear Chopin's influence. ${ }^{7}$ What is striking about this list is that the works enumerated, by and large, no longer figure prominently in the concert repertoire. Just as Chopin's students were for the most part unimportant pianists, so the concertos influenced by Chopin's are relatively minor works. Since Rink makes a strong case for the significance of Chopin's contributions to the history of the early-nineteenth-century piano concerto, it would be interesting to know his explanation for their limited sphere of influence. This is yet another matter that is approached and then abandoned for lack of space. In fact, as must be evident by now, Rink raises so many critical issues and provides so much food for thought that one wishes the book were much longer, which is high praise indeed.

The "principles and premises" upon which Rink constructs his re-evaluations involve "the symbiotic relationship between narrative and architecture." $\mathrm{He}$ first defines "each movement's skeletal structure, identifying important 'stabilising' features such as tonal scheme and sectional form, and then in tracing through the music [he observes] temporally defined processes like the generation and relaxation of momentum, rhythmic flux and small- and large-scale gestural impulse, all of which help to transform the structural bedrock into a living musical statement" (p. 45). In fact, Rink does much more. His frequent comparisons with the five concertos he believes most influenced ChopinHummel (opp. 85 and 89), Moscheles (op. 58), Kalkbrenner (op. 61), and Field (A-flat Major) -help the reader appreciate the myriad ways in Chopin's concertos differ from his contemporaries'. Nonetheless, criticisms of Field's "melodic constipation" and Kalkbrenner and Hummel's "gratuitous virtuosity" seem

\footnotetext{
${ }^{5}$ Ibid., 224.

${ }^{6}$ Ibid., 135.

${ }^{7}$ Ibid., 121 n. 58. See Hans Engel, Das Instrumentalkonzert (Leipzig, 1932; repr. ed., Wiebaden: Breitkopf \& Härtel, 1971)
} 
unnecessarily harsh. Surely, it is not vital to discredit the works of his contemporaries to elevate Chopin's works to the status they deserve. ${ }^{8}$

It is when Rink strays from evaluation into mere description that one of the book's more serious shortcomings becomes evident. That is, that Rink's focusre-evaluation-which is so clearly defined at the outset of the book, is sometimes lost in a forest of detail:

Moving through sequentially related keys-A-flat major (III), D-flat major (VI) and B-flat minor (iv), with a developmental circle-of-fifths progression to the last of these-the successive melodic statements finally reach the dominant minor, $\mathrm{C}$ minor, after which a furious ascent in both hands (starting in $\mathrm{F}$ minor) provokes a cascade of triplet quavers before the sedate orchestral conclusion, in which fragments of the first theme appear between antiphonal wind commentaries (p. 59).

Passages of this sort detract from Rink's otherwise clear focus. The editor could have excised lengthy descriptive passages without undermining the reevaluative process. The schematic diagrams of the form and tonal plan of each movement render features of Rink's prose narratives superfluous. They are also, at times, confusing. After pondering Rink's frequent references to Chopin "turning up the temperature" (pp. 48, 61, 65, 82), I am unable to determine what he actually means; does temperature have to do with volume, harmonic rhythm, virtuosity, some combination of these elements, or something else entirely?

Perplexing, too, is the lack of an explanation of the process by which the discography was compiled. We are told only that the discography derives from four sources (Kanski, two by Methuen-Campbell, and the National Sound Archive in London [p. 120 n. 50]), without learning how the author selected fortytwo of the more than four times this number of recordings commercially available. Suffice it to say that none of the "modern" recordings in my own collection-Cliburn/Ormandy (op.11), Pollini/Kletzki (op.11), Wild/Sargent (op.11), Bachauer/Dorati (opp. 11 and 21), Cherkassky/Kempe (op.21)-figure in Rink's discography, which says, I suppose, something about his taste and mine. It would appear that some of the recordings Rink does include are CDs, while others are unremastered 78-rpm and 33 1/3-rpm discs. Even in an abbreviated discography, it would have been helpful to distinguish between formats. Incidentally, I was at first dismayed to find the Allegro de concert omitted from the discography (it is, after all, a much more obscure work than the two concertos), but later discovered it incorporated into the text itself (pp. 94-95). It should have been included in appendix 3.

The question remains whether or not Rink succeeds in his objective "to set the record straight," to re-evaluate and thereby restore these works to their rightful place in the canon of the early-nineteenth-century piano concerto. The answer is a qualified yes. Rink observes that "Scholarly preoccupation with the Allegro de concert's chronology and 'stylistic inconsistencies' has diverted at-

${ }^{8}$ See also Rink's reiteration of Samson's unfavourable comparison of Weber, Hummel, Field, and Kalkbrenner with Chopin (p. 125 n. 28). 
tention from its 'profound effect' when actualised in sound-as in the case of op. 11 and op. 21, although for different reasons" (p. 95). It is a measure of the persuasiveness of Rink's arguments that readers will hear these works anew, armed with a volley of fresh insights. A handbook such as this can only help chart the course, and the listener, not the reader, will ultimately decide whether these pieces warrant the resounding endorsement Rink gives them.

Glen Carruthers

Andrew Thomson. Vincent d'Indy and His World. Oxford and New York: Clarendon Press, 1996. xv, 220 pp. ISBN 0-19-816220-0 (hardcover).

Should the Marlborough Man ever be in need of a more elderly persona, the classic and often-reproduced photo of a smoking Vincent d'Indy might easily substitute. With his focused gaze, bushy mustache, tensed jaw, and upper lip firmly clamped down on a cigarette, d'Indy evokes all the clichés of the macho cowboy smoker, even though he may not be wearing the proper outfit. In his recent biographical survey of Vincent d'Indy, Andrew Thomson has included not only this classic photo of the composer, but one of him smoking hands free while reading a score, and another of him holding a cigarette in a pastoral setting. Thomson's biography probably does not contain every picture ever taken of d'Indy smoking, nor is it a complete accounting of his life and work. To be fair, the author admits that the work is brief. Indeed, his stated purpose is not so much to tell all of d'Indy's story as to tell it in a different way. He wants to salvage d'Indy, known to have frequently expressed extreme right-wing political views, and portrayed by his earliest biographer, Léon Vallas, as emotionally frigid. Thomson feels that he will be able to do this using the evidence of the journal intime, which Vallas and other scholars were not able to consult.

Thomson's project is ambitious, but problematic. Its ambition lies in treating a highly complex subject: a man with many faces who lived during a time of enormous political, social, and cultural upheaval.Vincent d'Indy also espoused values and engaged in political activities that may be problematic if not distasteful from our current point of view. But unlike the case of Wagner, for instance, d'Indy's music has not become so entrenched in our institutions that his complicated life and convoluted ethical stances need to be reconciled with a continued fascination for his music. To the obvious question "what is the point of rehabilitating him?," Thomson answers, "My hope is that having put the underlying ideas and ideologies into historical perspective, his music will be listened to on its own, very considerable merits" (p.ix). Thomson wishes to prove to us that d'Indy was an important person in his time; that his aesthetic-often judged negatively today - was shared and approved of by others, that his political orientation was contemporaneously justifiable.

Thomson has made some assumptions here that I think should not be made so lightly. First, showing context might mitigate negative views of a person's behaviour and political ideology, but it will not necessarily lead to a more positive reception of his or her works. This seems to assume that we should only 